\title{
Synoptic comparison between two cases of subtropical cyclones in the South coast of Brazil
}

Subtropical Cyclones are low-pressure systems that occur in tropical or subtropical latitudes and that have characteristics of both tropical cyclones and extratropical cyclones. The subtropical class also has a thermodynamic forcing near the surface resulting from heat and humidity flows from the warm ocean. The objective of this study is to make a comparison between two cases of subtropical cyclones that occurred on the south coast of Brazil during the end of spring and summer periods in the Southern Hemisphere. The chosen cases were SC Cari and SC Eçai, which occurred respectively from March 10th to 13th of 2015 and from December 3rd to 6th of 2016. This study was carried out through the analysis of meteorological fields employing the ERA5 reanalysis data along with GOES-13 satellite imagery. In spite of both systems occurring on a similar spatial domain, their different atmospheric characteristics have an important part in their origin, intensity and trajectory. Their trajectories were of interest because of their uncommonness, where Cari moved at first towards the continent presenting risks to the society and only later moving towards the ocean till its dissipation. And Eçai formed over the land as a thermal low that moved towards the ocean gaining strength as it found warm waters, finding a new and more favorable environment.

Keywords: Cyclogenesis; Eçai; Cari; Trajectory.

\section{Comparação sinótica entre dois casos de ciclones subtropicais no litoral Sul do Brasil}

\begin{abstract}
Ciclones Subtropicais são sistemas de baixa pressão que ocorrem em latitudes tropicais ou subtropicais e que possuem características tanto de ciclones tropicais quanto de ciclones extratropicais. A classe subtropical também possui um forçamento termodinâmico próximo à superfície resultante dos fluxos de calor e umidade do oceano quente. $\mathrm{O}$ objetivo deste estudo é fazer uma comparação entre dois casos de ciclones subtropicais ocorridos na costa sul do Brasil durante os períodos de final de primavera e verão no Hemisfério Sul. Os casos escolhidos foram SC Cari e SC Eçai, que ocorreram respectivamente de 10 a 13 de março de 2015 e de 3 a 6 de dezembro de 2016. Este estudo foi realizado através da análise de campos meteorológicos empregando os dados de reanálise ERA5 juntamente com o GOES-13 Imagem de satélite. Apesar de ambos os sistemas ocorrerem em um domínio espacial semelhante, suas diferentes características atmosféricas têm um papel importante em sua origem, intensidade e trajetória. Suas trajetórias foram interessantes por causa de sua raridade, onde Cari se dirigiu primeiro para o continente apresentando riscos para a sociedade e só depois se dirigiu para o oceano até sua dissipação. E o Eçai formou-se sobre a terra como uma baixa térmica que se moveu em direção ao oceano ganhando força ao encontrar águas mornas, encontrando um ambiente novo e mais favorável.
\end{abstract}

Palavras-chave: Ciclogênese; Eçaí; Cari; Trajetória.

Topic: Meteorologia, Climatologia e Mudanças Climáticas

Reviewed anonymously in the process of blind peer.

Nathália Helena Teixeira Costa (iD)

Universidade Federal de Pelotas, Brasil

http://lattes.cnpq.br/6334504217359976

http://orcid.org/0000-0003-0752-0829

nathaliahtcosta@gmail.com

André Becker Nunes (iD

Universidade Federal de Pelotas, Brasil

http://lattes.cnpq.br/1873505066686878

http://orcid.org/0000-0002-4881-5810

beckernunes@gmail.com
Received: 04/07/2021

Approved: 27/07/2021
Referencing this:

COSTA, N. H. T.; NUNES, A. B.. Synoptic comparison between two cases of subtropical cyclones in the South coast of Brazil. Revista Ibero Americana de Ciências Ambientais, v.12, n.7, p.175-183, 2021. DOI: http://doi.org/10.6008/CBPC2179-6858.2021.007.0017 


\section{INTRODUCTION}

The National Oceanic and Atmospheric Administration (NOAA) defines Subtropical Cyclones as lowpressure systems that occur in tropical or subtropical latitudes (from Ecuador to around $40^{\circ}$ ) and that have characteristics of both tropical cyclones and extratropical cyclones. This means that many of these cyclones are formed in a region of low to moderate horizontal temperature gradient (such as mid-latitude cyclones). However, they also receive much of their energy from convective clouds (such as tropical cyclones), and can still undergo transitions and transform completely into Tropical Cyclones.

The subtropical class also has a thermodynamic forcing near the surface resulting from heat and humidity flows from the warm ocean. However, it has an environment of strong wind shear, which increases the likelihood of baroclinic development and, therefore, is the most suitable environment for subtropical cyclogenesis (GONZÁLES-ALEMÁN et al., 2015). The exchanges of latent and sensitive heat on the surface of the ocean are important mechanisms for transferring heat from the ocean to the atmosphere (CAYAN, 1992). The study of Subtropical Cyclones (SC) in the South Atlantic Ocean (SAO) contributes to our understanding of the global distribution and mechanisms underlying these intense weather systems (EVANS et al., 2012). It also serves as an important information tool and possible alerts system to areas or regions where the phenomenon is most prevalent or that may be affected by this type of storm.

Thus, the objective of this study is to make a comparison between two cases of subtropical cyclones that occurred on the south coast of Brazil during the end of spring and summer periods in the Southern Hemisphere. The chosen cases were SC Cari and SC Eçai, which occurred respectively from March $10^{\text {th }}$ to $13^{\text {th }}$ of 2015 and from December $3^{\text {rd }}$ to $6^{\text {th }}$ of 2016. Subtropical cyclones are not as intense as Tropical Cyclones (TC), however these cases were considered interesting due to their unusual trajectories and the potential impacts for society in one of the most populated regions of Brazil.

\section{METHODOLOGY}

This study was carried out for the Subtropical Cyclone Cari, which occurred on south the Brazilian coast in the period from March $09^{\text {th }}$ to $13^{\text {th }}$ of 2015 and for the Subtropical Cyclone Eçai, formed over the region of the Chaco-Low from December $3^{\text {rd }}$ to $6^{\text {th }}$ of 2016. Data from ERA5 (The fifth generation European Centre for Medium-Range Weather Forecasts - ECMWF reanalysis for the global climate and weather HERSBACH et al., 2020) were used, with spatial resolution of $0.25^{\circ} \times 0.25^{\circ}$ and temporal resolution of 6 hours, from the surface to the pressure level of $100 \mathrm{hPa}$.

The variables considered for the study were mean sea level pressure (MSLP), air temperature at 850 $h P a(T)$, zonal wind component $(u)$ and meridional wind component $(v)$, geopotential height $(h)$, relative humidity (RH), specific humidity (q), potential vorticity (PV) and vertical velocity $(\Omega)$ at different vertical levels, surface latent heat flux (SLHF) and sea surface temperature (SST) at the synoptic hours of 0000, 0600, 1200 and 1800 UTC (Universal Coordinated Time).

Images from the GOES-13 satellite, in the water vapor channel, obtained from the Satellite and 
Environmental Systems Division of the National Institute for Space Research (DSA/INPE). The SC were visually identified based on the generated MSLP fields, observing the criteria of genesis between $20^{\circ} \mathrm{S}$ and $40^{\circ} \mathrm{S}$; equivalent in the southern hemisphere to the criteria used in the northern hemisphere (EVANS et al., 2009).

To identify the beginning of the cyclone genesis, it was chosen the first time where a closed isobar is identified in the latitudinal region defined by Evans et al. (2009) in the south-southeast region of Brazil and for the SC dissipation, the time when the closed isobar loses its very circular characteristic, dissipating in the SAO well away from the Brazilian coast and no longer presenting risks to society.

\section{RESULTS AND DISCUSSION}

On Fig.1a (SC Cari) it was identified a low-pressure system over the ocean as marked on the MSLP field at 06 UTC March $6^{\text {th }} 2015$ defined as genesis of the subtropical cyclone, this subtropical structure can be a precursor for Tropical Transition (TT) according to McTaggart-Cowan et al. (2006) and so valuable for this study. On Fig.1b (SC Eçai) the low-pressure system was identified forming over the Chaco region on the continent, being thermically induced by the warming of the low and medium troposphere as indicated in the study by Seluchi and Saulo (2012). As a thermal low the system has weak surface winds which does not present great risks to the society.

The day before the formation (not shown) of the SC Cari there was a weak low system on the coast the states of Paraná e São Paulo, on the morning of March $10^{\text {th }} 2015$ this system gets a more circular shape and gains strength moving towards the ocean. As is reaches warm waters it gets a more suitable environment which provides the system with humidity from the evaporation of the ocean, inducing more convection in the region. Cari (Fig.2a) formed over a region of relatively warm SST (varying from $24^{\circ} \mathrm{C}$ to $30^{\circ} \mathrm{C}$ ) then spiraled towards the continent in what looks like an attempt to sustain its convection, instead of moving towards the ocean poleward as it should. It remained in that warm SST region for most of its life time while slowly taking its expected southwestward trajectory towards the ocean till its dissipation (Fig.2a). This trajectory is expected for subtropical cyclones due to the temperature advection (BLUESTEIN, 1993). Their trajectories are of interest because of their uncommonness (considering what is expected for an extratropical cyclone due to the subtropical cyclones hybrid nature), where Cari moved at first towards the continent presenting risks to the society and only later moving towards the ocean till its dissipation. While Eçai formed over the land as a thermal low (weak surface wind) that moved towards the ocean gaining strength, as it found a new and more favorable environment.

As for the SC Eçai on the day before its genesis there was only the continental low present over the Chaco region and on the morning of December $3^{\text {rd }} 2016$ the continental low evolved to a weak low-pressure system in that region. As the day passes this weak low-pressure system moves eastward crossing the Chaco region and the state of Santa Catarina, reaching the warm ocean which fuels the system providing the necessary condition (humidity) for the intensification (Fig.2b). Eçai originated in a warm continental low and intensified over SST from $21^{\circ} \mathrm{C}$ to $24^{\circ} \mathrm{C}$, that means that the system formed over lower SST values than SC Cari, possibly due to the fact that SC Eçai occurred in the end of spring while SC Cari occurred in the end of 
summer in the Southern Hemisphere.
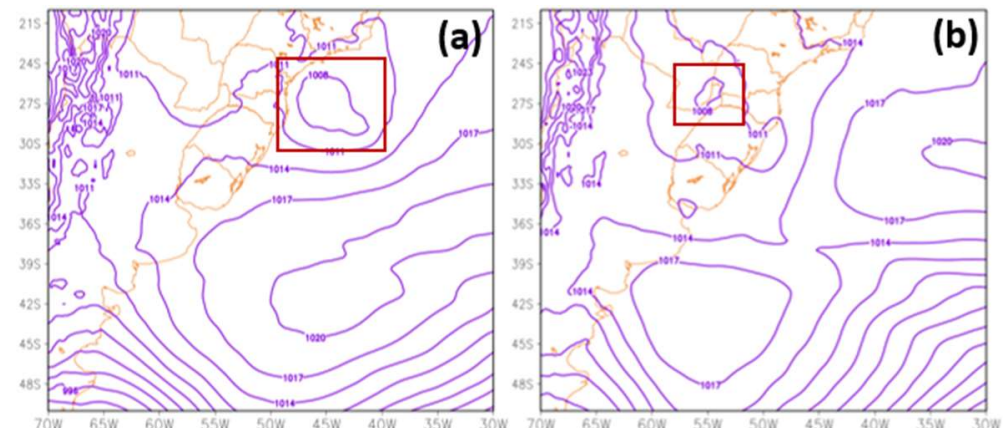

Fig. 1: MSLP (contour) of Day 1 (genesis) for (a) SC Cari, 06 UTC March $10^{\text {th }} 2015$ and (b) SC Eçai, UTC 12UTC December $3^{\text {rd }} 2016$, the red rectangles indicate the cyclone's formation area.
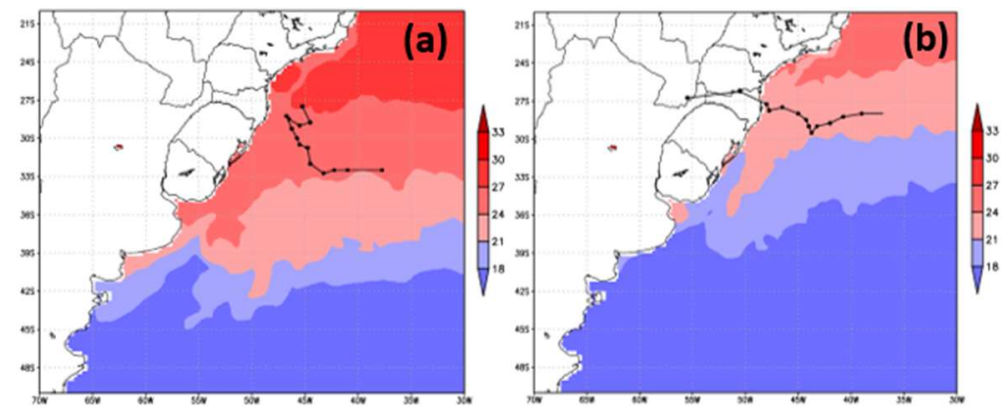

Fig. 2:Trajectories (lines - dots with $6 \mathrm{~h}$ interval) and Mean Sea Surface Temperature(shaded) in ${ }^{\circ} \mathrm{C}$ for (a) SC Cari from 06UTC March $10^{\text {th }}$ to 18 UTC March 13 ${ }^{\text {th }} 2015$; (b) SC Eçai from 12UTC December $3^{\text {rd }}$ to 18 UTC December $6^{\text {th }} 2016$.

Observing the wind fields at $850 \mathrm{hPa}$ (Figs. 3a and 3b) for both SC is noticeable the typical logarithmic spiral characteristic (BJERKNES, 1919) or "comma shaped pattern" for these kind of severe weather systems, with stronger winds on the edges and weaker winds at the center of the system. Also, SC Eçai has wind speed values higher that $16 \mathrm{~ms}^{-1}$ (31 kt) throughout the system while SC Cari only presents values higher than that in some sectors. By comparing both figures it is possible to infer that one of the main differences between them is their intensity, on Fig.3a the SC Cari has a higher MSLP value (1002 hPa) than for SC Eçai (996 hPa) on Fig.3b. That means that the horizontal pressure gradient is stronger and more concentric on SC Eçai than on SC Cari.
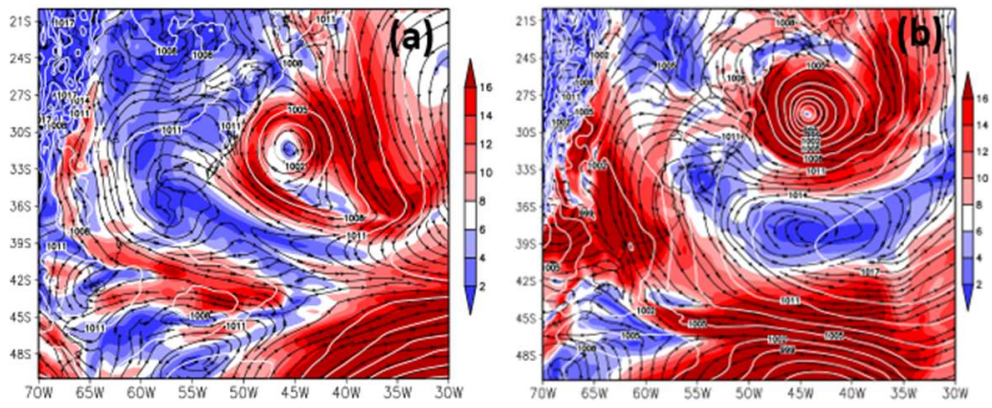

Fig. 3: Wind (streamlines and shaded in $\mathrm{ms}^{-1}$ ) at $850 \mathrm{hPa}$ for the days with the smallest MSLP (contour) values: (a)SC Cari at 06UTC March 12th of 2015; (b) SC Eçai at 00UTC December 5th 2016.

In the SLHF fields, the negative values indicate ascending latent heat fluxes representing the fluxes leaving the soil/ocean into the atmosphere and as we can see in Figures $4 a$ and $4 b$, there are intense flux values (between $150 \sim 300 \mathrm{Wm}^{-2}$ ) in the region of the ocean where the SC Cari is shown and (between $200 \sim$ $350 \mathrm{~W} / \mathrm{m}^{2}$ ) in the region of the ocean where the SC Eçai is shown. The highest SLHF values were found to be 
present in the cold sector of each cyclone (due to the cold air mass being dryer), between $25^{\circ}-38^{\circ} \mathrm{S}$ and $55^{\circ}$ $-40^{\circ} \mathrm{W}$ for SC Cari and between $23^{\circ}-34^{\circ} \mathrm{S}$ and $50^{\circ}-40^{\circ} \mathrm{W}$ for SC Eçai.

The days discussed in the SLHF fields were chosen because they were considered the most intense days during each cyclone's life time. The surface latent heat flux along with the sensitive heat flux, act as a forcing mechanism for the development of east coast cyclogenesis (PIVA et al., 2008). At first, due to the passage of cold air on the surface, the ocean loses heat to the atmosphere creating more intense latent heat fluxes gradients as noted by Sutil et al. (2019). The release of this latent heat into the atmosphere is due to the evaporation of the ocean so the humidity present in the lower layer of the atmosphere converges to the center of the system and is then transported vertically, causing deep cloudiness which induces strong winds and precipitation (COSTA et al., 2019). However, it was not observed a significant SST gradient (not shown) as it is expected in extratropical cyclones cases.

By analyzing the $\mathrm{SH}$ fields for both cyclones individually it is possible to confirm the presence of higher values of humidity from the continent and the ocean towards the center of the system. On Fig.5a (the formation of the cyclone) it is noticeable the high humidity from the continent entering the system in the same pattern as the wind flows (figs. 3a and $3 b$ ), moving southeasterly and then spiraling back northwestward converging in the center of the cyclone. At its most intense day the highest values of SH are found exactly in the center of SC Cari as shown in Fig.5b, confirming the analysis made earlier in this study.
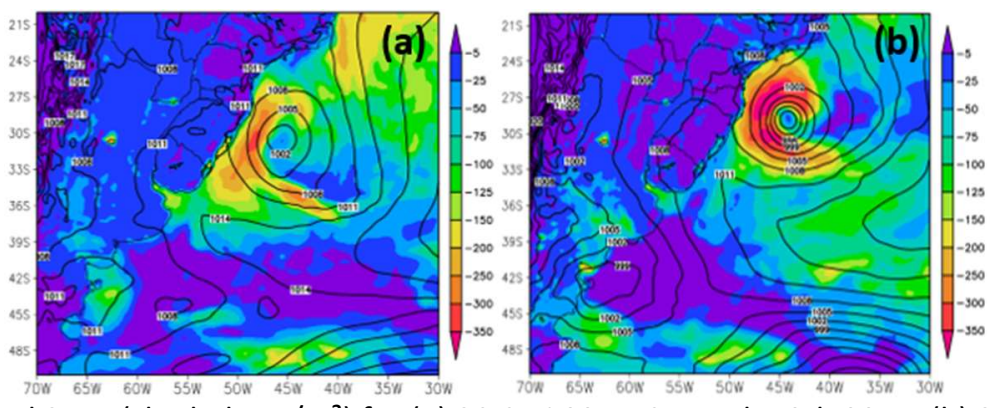

Fig. 4: MSLP (contour) and SLHF (shaded - W/m²) for (a) SC Cari 00 UTC March 12th 2015; (b) SC Eçai O6UTC December 5th 2016.

As for SC Eçai, on the day of its formation the highest values of $\mathrm{SH}$ are found in the Chaco region and in the west of the states of Paraná and Santa Catarina providing the cyclone with the necessary humidity and convection during its passage over the continent as Fig.6a shows. As SC Eçai reaches the coast and finds the ocean, the humidity from the continent and the ocean flows into the system being transported to the center and maintaining its convection, with it the cyclone gains strength and becomes more intense as shown in Fig.6b. Once more, confirming the analysis of the wind and latent heat fluxes fields made earlier in this study.

By observing the thickness field, it is possible to identify the temperature advection configuration in both cyclone cases Fig.7a and 7b. In the two cases there was warm air advection from the tropics providing a mass of hot, humid air southward to the cyclones' cores which not only acts like a forcing to the development of the system but also by consequence expands the atmospheric layer in the region where the cyclones are. This effect is a clear evidence of the maintenance of deep convection in these kinds of severe weather systems. 

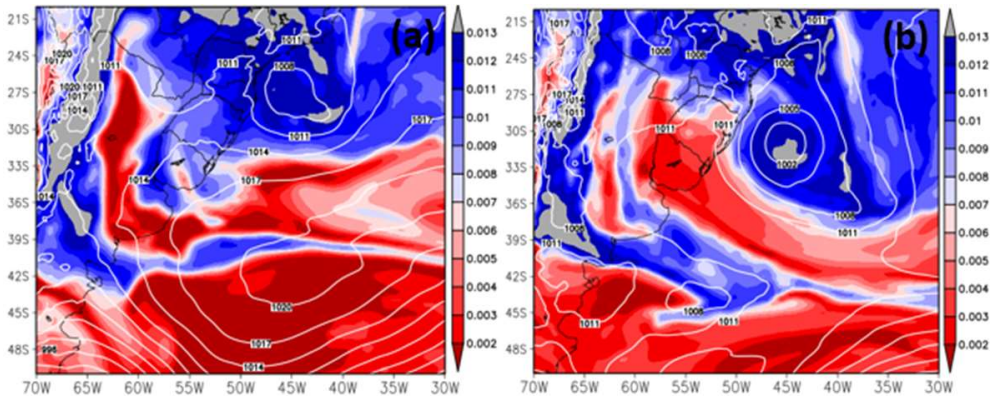

Fig. 5: MSLP (contour) and Specific Humidity (shaded, $\mathrm{kg} \mathrm{kg}^{-1}$ ) at 850hPa for SC Cari: (a) 06 UTC March 10th 2015; (b) 06 UTC March 12th 2015.
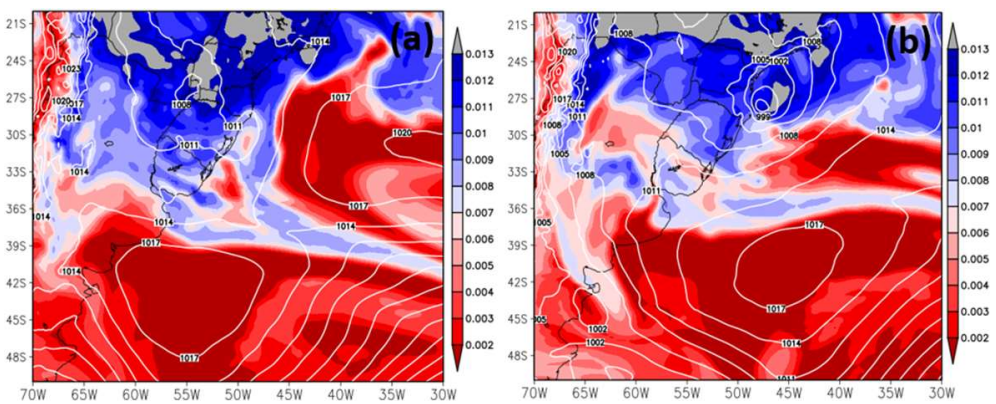

Fig. 6: MSLP (contour) and SH (shaded, $\mathrm{kg} \mathrm{kg}^{-1}$ ) at 850hPa for SC Eçai: (a) 12 UTC Dec $3^{\text {rd }} 2016$; (b) 06 UTC Dec $4^{\text {th }} 2016$.

Also, there was cold air advection from the polar region northward and this temperature gradient helps support the thermal low, in the case of SC Eçai, by transforming it in a dynamic low as it reaches stronger temperature gradients, due to the cyclone continuing its trajectory southward (not shown). SC Cari is coherent with the Shapiro and Keyser conceptual model for cyclones, while SC Eçai is coherent with the Bjerknes et al. (1992) conceptual model for cyclones.

Another aspect that is important to mention is the geopotential height at $500 \mathrm{hPa}$ which has been used since the earlier extratropical cyclones' studies, but also plays an important role to understanding the subtropical cyclones' dynamics (OLIVEIRA et al., 2019). Figure 8a shows that there was a closed center of geopotential height present at the middle troposphere meaning that CS Cari formed as a barotropic system and remained as such throughout its life time (not shown). Differently from Cari, Eçai formed as a thermal low (not shown) and as it reaches the ocean and finds greater temperature gradients begins to demonstrate a baroclinic characteristic until it becomes fully barotropic at 06 UTC December $5^{\text {th }} 2016$ as shown in Fig. 8b, remaining barotropic till the system dissipates far in the ocean (not shown).
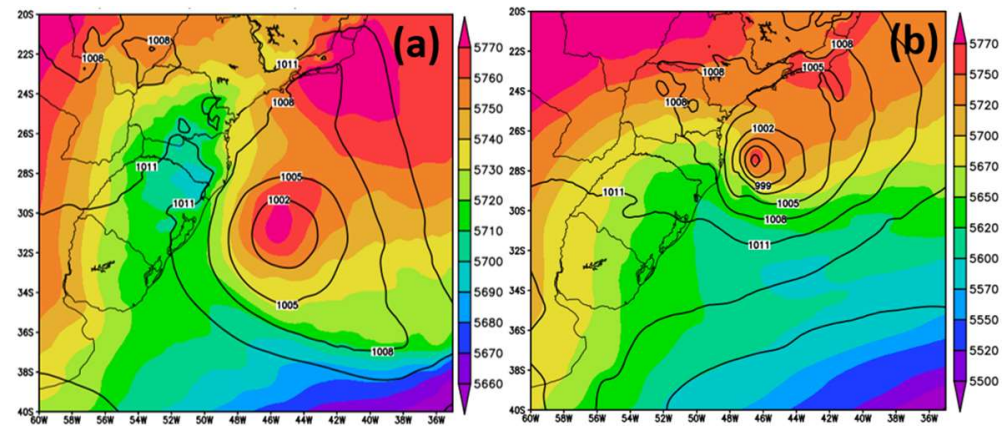

Fig. 7: MSLP (contour) and Thickness 1000 - 500hPa (shaded) for (a) SC Cari 06UTC March 12th 2015 and (b) SC Eçai 12 UTC December 4th 2016. 


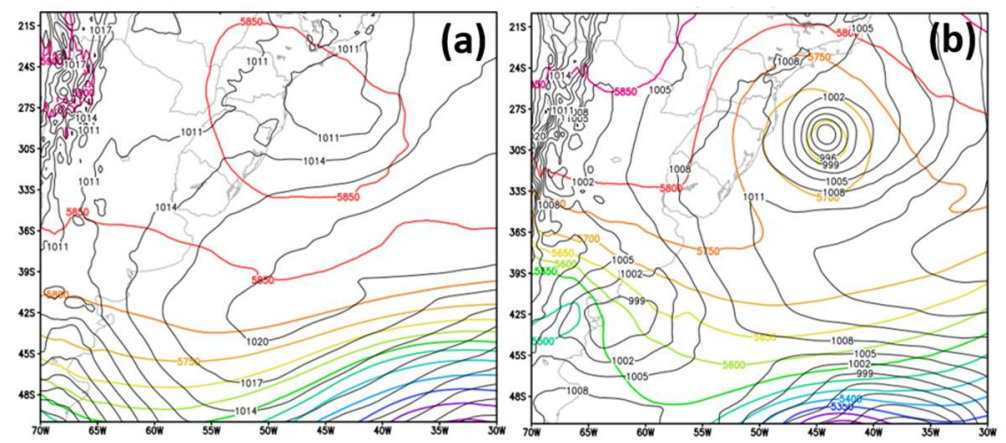

Fig. 8: MSLP (black contour) and Geop. Height (color contour) for (a) SC Cari 00UTC March 10th 2015 and (b) SC Eçai 06UTC Dec 5th 2016.

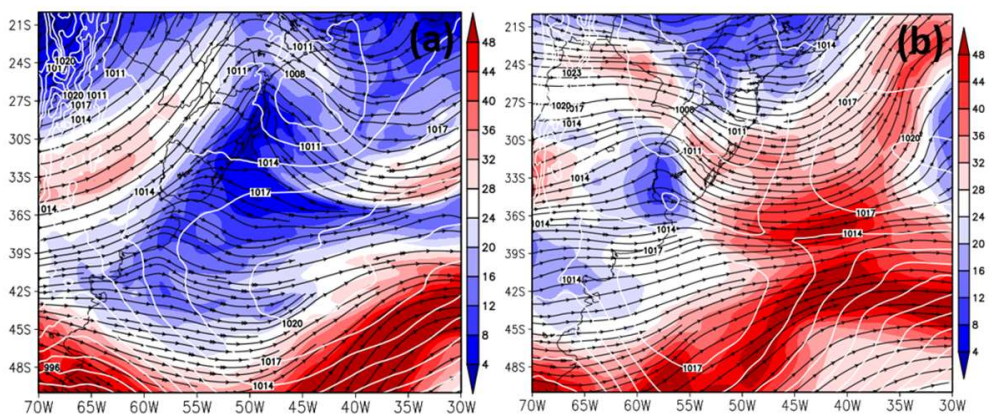

Fig. 9: MSLP (contour) and Wind at 250hPa (streamlines) for (a) SC Cari 06UTC March 10th 2015 and (b) SC Eçai 12 UTC December 3rd 2016.

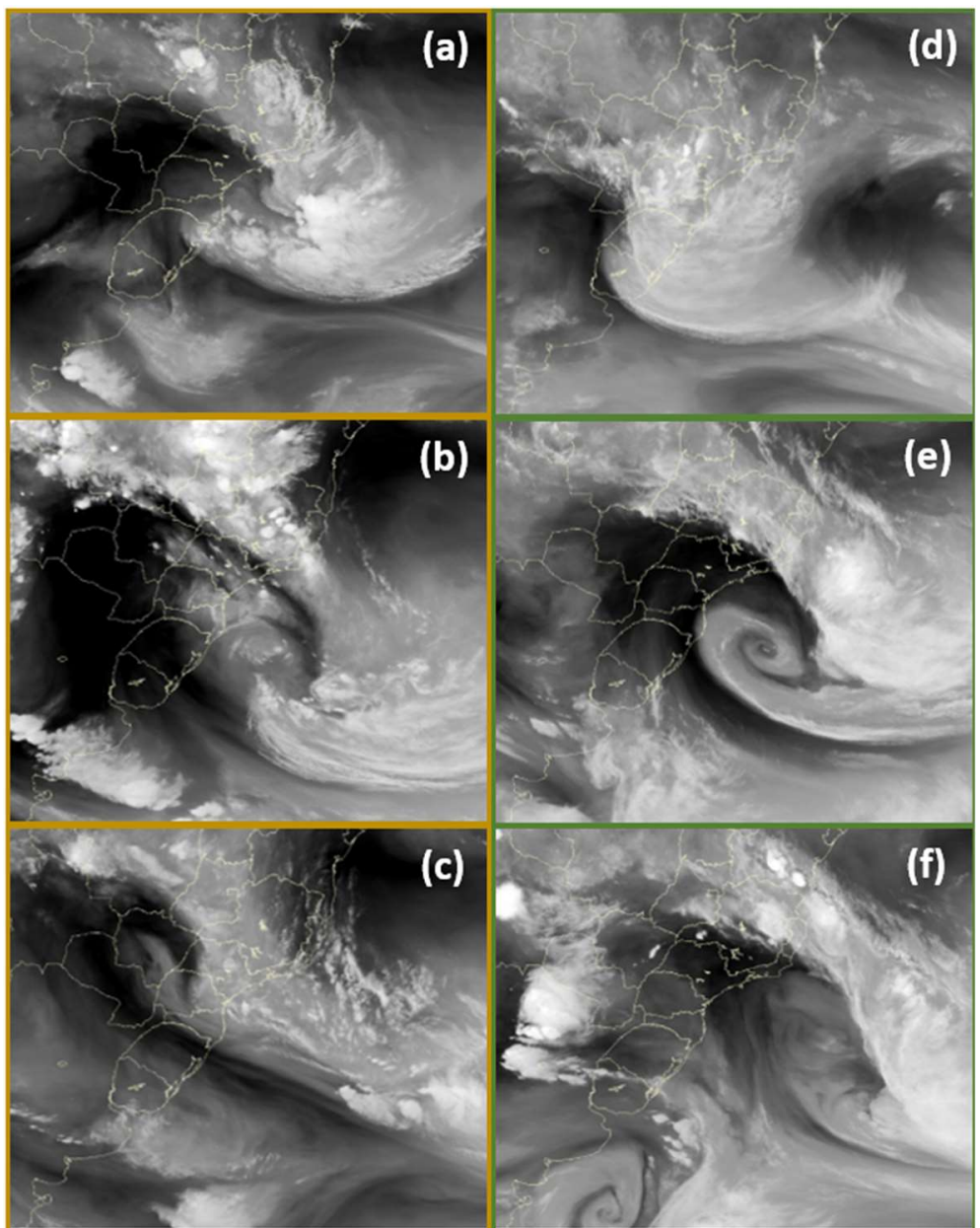

Fig. 10: Water Vapor channels of GOES 13 satellite: (a) SC Cari 12UTC March 10th 2015; (b) SC Cari 00UTC March 12th 2015; (c) SC Cari 12UTC March 13th 2015; (d) SC Eçai 12UTC Dec 3rd 2016; (e) SC Eçai 12UTC Dec 5th 2016; (f) SC Eçai 06UTC Dec 6th 2016.

When analyzing the upper levels of the atmosphere for SC Cari it was identified the presence of a strong diffluence in the southwest flank of the cyclone (fig. 9a), this air mass removal effect of the upper- 
level flow along with the instability of the layer due to the warm air advection is a very suitable environment for the cyclogenesis (GOZZO et al., 2014). This diffluence gains strength in the following days (not shown) resulting in a McTaggart-Cowan et al. (2006, cited by REBOITA et al., 2017) dipole blocking, keeping the cyclone stationary until that configuration weakens and the cyclone is able to continue its trajectory into the ocean until it dissipates.

For SC Eçai, in the upper atmosphere, there is a much smaller diffluence downstream of the cyclone and a mild jet stream west of the system (fig. 9b). As the days go by (not shown) and the system reaches the ocean this diffluence intensifies and the jet streams positioned north and south of the cyclone act the same as in SC Cari, helping maintaining the cyclone's stationary characteristic for a few days. Once the diffluence weakens the jet stream allows the system to continue its expected trajectory towards the ocean. Both subtropical cyclones formed slightly eastward of the upper-level trough. This cold/warm occlusion configuration is very noticeable in the water vapor channels of GOES 13 satellite as shown in Figures 10a to $10 f$.

\section{CONCLUSIONS}

He present study analyzed two summer cases of subtropical cyclones that occurred in the south coast of Brazil. In spite of both systems occurring on a similar spatial domain, their different atmospheric characteristics have an important part in their origin, intensity and trajectory. Subtropical Cyclone Cari occurred from March $10^{\text {th }}$ to $13^{\text {th }}$ of 2015 whereas Subtropical Cyclone Eçai occurred from December $3^{\text {rd }}$ to $6^{\text {th }}$ of 2016 both having a life cycle of 3 days. The cyclogenesis happened with very different heat and humidity sources over relatively different SST environments, the first formed over the ocean not far from the coast the states of Santa Catarina, Paraná and São Paulo and the latter formed over the Chaco region in Paraguay (depending of the temperature gradients) then moved towards the ocean where it gained strength and acquired a more barotropic characteristic.

Their trajectories were of interest because of their uncommonness (considering what is expected for an extratropical cyclone - due to the subtropical cyclones hybrid nature), where Cari moved at first towards the continent presenting risks to the society and only later moving towards the ocean till its dissipation. While Eçai formed over the land as a thermal low (weak surface wind) that moved towards the ocean gaining strength, as it found a new and more favorable environment.

The analysis of the surface latent heat flux, relative humidity, thickness and wind in the upper levels are all in concordance with the contributions of the warm and cold branches for each of the systems. SC Cari, a system of completely barotropic nature, was considered to be a weaker subtropical cyclone than Eçai a system of baroclinic nature, which started weak and became much more intense as it reached the coast and became barotropic. After a few days as semi stationary near the south coast of Brazil SC Eçai weakens and dissipates far into the ocean.

ACKNOWLEDGEMENT: The authors were supported by Fundação de Amparo à Pesquisa do Estado do Rio 
Grande do Sul (FAPERGS).

\section{REFERENCES}

BJERKNES, J.. On the structure of moving cyclones. Geofysiske Publikasjoner, v.1, n.2, p.1-8, 1919.

BJERKNES, J.; SOLBERG, H.. Life cycle of cyclones and the polar front theory of atmospheric circulation. Geofysiske Publikasjoner, v.3, p.3-18, 1922.

BLUESTEIN, H. B.. Synoptic-Dynamic Meteorology in Midlatitudes: Volume 2: Observations and Theory of Weather Systems. Oxford University Press USA, 1993.

CAYAN, D. R.. Latent and sensible heat flux anomalies over the northern oceans: the connection to monthly atmospheric circulation. Journal of Climate, v.5, p.354-369, 1992. DOI: http://doi.org/10.1175/1520-0442

COSTA, N. H. T.; NUNES, A. B.. Análise do fluxo de calor latente para o ciclone subtropical cari. In: ENCONTRO DE METEOROLOGIA DO ESTADO DE SANTA CATARIANA, 2; ENCONTRO SUL BRASILEIRO DE METEOROLOGIA, 8. Anais. Florianópolis, 2019.

EVANS, J. L.; BRAUN, A.. A climatology of Subtropical Cyclones in the South Atlantic. Journal of Climate, Boston, v.25, p.7328-7340, 2012.

EVANS, J. L.; GUISHARD, M. P.. Atlantic subtropical storms. Part I: Diagnostic criteria and composite analysis. Monthly Weather Review, v.137, n.7, p.2065-2080, 2009.

GONZÁLES-ALEMÁN, J. J.; MARTÍN-LEÓN, F.; EVANS, J. L.. Classification and Synoptic Analysis of Subtropical Cyclones within the Northeastern Atlantic Ocean. Journal of Climate, Boston, v.28, p.3331-3352, 2015.

GOZZO, L. F.; ROCHA, R. P.; REBOITA, M. S.; SUGAHARA, S.. Subtropical cyclones over the southwestern South Atlantic: climatological aspects and case study. Journal of Climate, v.27, p.8543-8562, 2014.

HERSBACH, H.; BELL, B.; BERRISFORD, P. et al.. The ERA5 global reanalysis. Q J R Meteorol Soc., v.146, p.1999-2049, 2020. DOI: https://doi.org/10.1002/qj.3803

MCTAGGART-COWAN, R.; BOSART, L. F.; DAVIS, C. A.; ATALLAH, E. H.; GYAKUM, J. R.; EMANUEL, K. A.. Analysis of hurricane Catarina (2004). Monthly Weather Review, v.134, p.3029-3053, 2006.

OLIVEIRA, J.. Extratropical transition of subtropical cyclones over southwestern Atlantic Ocean. Tese (Doutorado em Meteorologia) - Instituto Nacional de Pesquisas Espaciais, São José dos Campos, 2019.

PIVA, E. D.; MOSCATI, M. C. L.; GAN, M. A.. Papel dos fluxos de calor latente e sensível em superfície associado a um caso de ciclogênese na costa leste da américa do sul. Revista Brasileira de Meteorologia, v.23, n.4, 450-476, 2008.

SUTIL, U. A.; PEZZI, L. P.; ALVES, R. C. M.; NUNES, A. B.. Ocean-Atmosphere Interactions in an Extratropical Cyclone in the Southwest Atlantic. Anuário do Instituto de Geociências, v.42, n.1, p.525-535, 2019.

A CBPC - Companhia Brasileira de Produção Científica (CNPJ: 11.221.422/0001-03) detém os direitos materiais desta publicação. Os direitos referem-se à publicação do trabalho em qualquer parte do mundo, incluindo os direitos às renovações, expansões e disseminações da contribuição, bem como outros direitos subsidiários. Todos os trabalhos publicados eletronicamente poderão posteriormente ser publicados em coletâneas impressas sob coordenação da Sustenere Publishing, da Companhia Brasileira de Produção Científica e seus parceiros autorizados. Os (as) autores (as) preservam os direitos autorais, mas não têm permissão para a publicação da contribuição em outro meio, impresso ou digital, em português ou em tradução. 